\title{
Improving composition and microbiological characteristics of milk kefir using colostrum
}

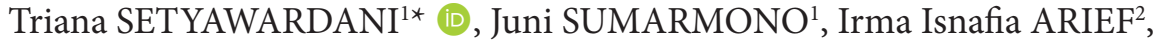 \\ Agustinus Hantoro Djoko RAHARDJO ${ }^{1}$, Kusuma WIDAYAKA ${ }^{1}$, Singgih Sugeng SANTOSA ${ }^{1}$
}

\begin{abstract}
Kefir characteristics are influenced by raw materials. Fresh milk and colostrum have different characteristics. In this research, colostrum was used as additional material in kefir production which could affect the chemical, microbiological, and antimicrobial properties of final the product. This study was aimed to investigate the chemical and microbiology properties of kefir prepared from milk, colostrum and milk-colostrum mixes. Kefir was prepared by adding kefir grains to $100 \%$ fresh milk, milk-colostrum mixes (20:80\%; 40:60\%; 60:40\%; 80:20\%) and 100\% colostrum. Fermentation was allowed under room temperature for 24 hours. Results showed that all treatments produced kefir with relatively similar titrable acidity, free fatty acids, and fat contents. The highest levels of ethanol, total solids and protein content were observed in kefir produced from $100 \%$ colostrum. The average total microbes were $6.37-7.51 \log \mathrm{CFU} / \mathrm{ml} ; 7.04-8.23 \log \mathrm{CFU} / \mathrm{ml}$ bacteria; $6.92-7.48 \log \mathrm{CFU} / \mathrm{ml}$ $\mathrm{LAB}$ and 5.54-6.55 $\log \mathrm{CFU} / \mathrm{ml}$ yeast. Water activity values ranged from 0.85 to 0.89 . The highest microbial and antimicrobial properties were shown by kefir produced from milk-colostrum mix of $20: 80 \%$.
\end{abstract}

Keywords: colostrum; kefir; cow milk.

Practical Application: The addition of colostrum to the milk before fermentation improves the quality characteristics of milk kefir.

\section{Introduction}

Kefir is a product with sour flavor, a hint of ethanol and $\mathrm{CO}_{2}$ from the fermentation process using kefir grains. This fermented milk is different from the other fermentation products such as yogurt in terms of the chemical properties and the type of microbes involved. The predominant microorganisms in kefir include lactobacilli (9.03-9.92 log cfu/g), lactococci (9.56-11.51 log cfu/g) and yeasts (3.09-5.90 log cfu/g) (Zeynep et al., 2018). It has been reported that kefir exhibits probiotic activity and have health-enhancing properties (Silva et al., 2018). Kefir possessed an antibacterial properties against E. coli D157: $\mathrm{H} 7$ and S. aureus as reported by Kivanc \& Yapici (2018). Antimicrobial properties of kefir can be articulated to its low $\mathrm{pH}$ and metabolites produced by kefir microorganisms, such as specific peptides (bacteriocin) and exopolysaccharide (Kim et al., 2016).

Milk kefir can be manufactured from fresh milk of cows, buffaloes, sheep, goats as well as soy-milk. These raw materials affect the composition and characteristics of kefir. For example, kefir of buffalo milk has been reported to have higher exopolysaccharides, water holding capacity, and firmness compared to kefir of cow milk (Gul et al., 2018). Supplementing cow milk with soy milk and the use of probiotic bacteria Bifidobacterium longum produced kefir with high functional properties and flavor, which sourced from acetoin and diacetyl (Karaçalı et al., 2018). In addition to direct consumption, kefir can be used as a substitute of yogurt during manufacture of other fermented foods such as Tarhana (Demirci et al., 2019).
Bovine colostrum refers to the initial milk produced immediately after parturition of cows, and usually given to the calves. The composition and characteristics of colostrum are different from milk. Colostrum is a rich source of essential nutrients and its use in functional foods and food supplements has received substantial considerations (Ceniti et al., 2019; Hyrslova et al., 2016; Silva et al., 2019). Bioactive components of colostrum include growth factors, immunoglobulins, lysozyme, lactoferrin, oligosaccharides, and some immunomodulatory peptides (Hyrslova et al., 2016). Time of milking determines the concentration of bioactive components; for example Ceniti et al. (2019) reported that immunoglobulins in colostrum decreased from $93.36 \mathrm{~g} / \mathrm{L}$ to $5.53 \mathrm{~g} / \mathrm{L}$ in 48 hours.

Incorporation of colostrum for manufacturing kefir is a novelty, because although colostrum is rich of nutrients and other functional components, the use of colostrum or milk-colostrum mixes to produce kefir has not been comprehensively considered. Therefore, it was sensible to improve the quality characteristics of kefir as one of functional foods by mixing colostrum and milk. Our hypothesis was that incorporation of colostrum to milk would increase the functionality, and also affects other quality characteristics of kefir produced. Therefore, this study was aimed to evaluate the chemical and microbiological characteristics of kefir manufactured from milk, colostrum and milk-colostrum mixes. 


\section{Materials and methods}

\subsection{Materials}

Cow's whole milk and colostrum are obtained from a group of dairy farmers in Baturraden, Central Java, Indonesia. Kefir grains were obtained from the grains grown in the Laboratory of Animal Products Technology, Faculty of Animal Science, Jenderal Soedirman University, Indonesia.

\subsection{Kefir manufacture}

The procedure of making kefir was according to Setyawardani \& Sumarmono (2015). Fresh cow's milk, colostrum, and milk-colostrum mixes (20:80\%; 40:60\%; 60:40\%; 80:20\%) were pasteurized at $72{ }^{\circ} \mathrm{C}$ for $15 \mathrm{sec}$, then cooled to $28^{\circ} \mathrm{C}$. Kefir grains were added at a rate of $5 \%$ and incubated at $28^{\circ} \mathrm{C}$ for 24 hours to allow fermentation process. Milk kefir was separated from kefir grains using a fine plastic strainer for further treatments. Kefir grains were placed in a plastic container for another batch of fermentation.

\subsection{Chemical analysis}

Kefir composition - total solids, protein, and fat contents - was analyzed using a standard method (Association of Official Analytical Chemists, 2006). The ethanol of kefir was measured using a refractive index. The titratable acidity and free fatty acids were determined using the titration method.

\subsection{Determination of fatty acids}

A total of 20-30 mg fat was added with $1 \mathrm{ml} \mathrm{NaOH} 0.5 \mathrm{~N}$ in methanol, then headed in a water bath for 20 mins (Association of Official Analytical Chemists, 2006). A 2-ml BF3 20\% was incorporated and reheat for another 20 mins. The sample was let cool and added with $2 \mathrm{ml}$ saturated $\mathrm{NaCl}+1 \mathrm{ml}$ isooctane/hexane then shaken and put into a tube filled with $0.1 \mathrm{~g} \mathrm{Na}_{2} \mathrm{SO}_{4}$ anhydrate and let sit for 15 mins. The liquid phase was separated, and the organic phase was injected into chromatography gas. The condition of chromatography gas included 1:80 split ration, $1 \mu$ injection volume, and $23.6 \mathrm{~cm} / \mathrm{sec}$ linear velocity. A $1 \mu \mathrm{L}$ FAME standard mixture was injected. When all the peaks were out, $1 \mathrm{ml}$ of the prepared sample was injected. The retention time and peak of each component were measured then compared with the standard to gain information on the type of the component.

\subsection{Amino acid analysis}

Kefir amino acid was evaluated using HPLC. The pre-hydrolyzed sample in $10 \mathrm{ml} \mathrm{HCl} 0.01$ was filtered using millipore paper. Pre-column sample analysis was conducted by adding Buffer Kalium Borat $\mathrm{pH} 10.4$ with a 1:1 ratio. In an empty vial, $5 \mu \mathrm{L}$ sample was added with $25 \mu \mathrm{L}$ OPA and let sit for $1 \mathrm{~min}$ for perfect derivatization. As much as $5 \mu \mathrm{L}$ solution was injected into the HPLC column to expect a thorough amino acid separation within 25 mins. Analyzing the post-column sample was conducted by incorporating a $1 \mathrm{~mL}$ sample into an empty vial then injected using an autosampler.

\subsection{Microbiological analysis}

One $\mathrm{ml}$ kefir sample was mixed with nine $\mathrm{ml}$ solvent $\mathrm{NaCl}$ $0.98 \%$ and homogenized using a vortex (Velp Zx3 type, Italy) in a test tube as the first-stage dilution followed by a multilevel dilution. The dilutions of total microbe, total bacteria, and LAB were conducted up to $10^{6}$ and $10^{5}$ for total yeast. Applying a pour plate method, one $\mathrm{ml}$ of each microorganism was grown in different media, i.e., PCA (Oxoid, UK) for total microbial; NA (Oxoid, UK) for total bacterial; MRSA (Merck) for total LAB; and PDA (Oxoid, UK) for yeast. A petri dish containing the sample and media was incubated at $37-40^{\circ} \mathrm{C}$ for 24 hours to gather data on total microbial, total bacterial, and total yeast. In contrast, the LAB was incubated for 48 hours (Setyawardani \& Sumarmono, 2015).

\subsection{Measurement of antimicrobial properties}

The experiment bacterial cultures, i.e., S. typhimurium (ATCC 14028), E. coli (ATCC 8739), S. aureus (ATCC 25923), and $P$. aeruginosa (ATCC 9027) were stored at $5^{\circ} \mathrm{C}$ and refreshed weekly as a culture stock. Culture stock was diluted to obtain $6 \log \mathrm{CFU} \mathrm{ml} \mathrm{m}^{-1}$ population prior to evaluation. A total of $10 \mathrm{ml}$ kefir sample was centrifuged (PLC series, Germany) at $3500 \mathrm{rpm}$ speed for 15 minutes (Kim et al., 2016). As much as $20 \mu \mathrm{l}$ indicator bacteria was placed in a petri dish and added with $20 \mathrm{ml}$ of Mueller Hinton Agar. The agar was let sit then wells of $5 \mathrm{~mm}$ diameter were punched into the agar and filled with $20 \mu \mathrm{l}$ sample kefir for antimicrobial activity test and allowed to diffuse at low temperature $\left(5-8{ }^{\circ} \mathrm{C}\right)$ for 60 mins. The petri dish was incubated at $37^{\circ} \mathrm{C}$ for $24 \mathrm{~h}$. The clear zone forming in the well was measured using a caliper. Measurement was conducted three times at different locations to obtain the average value.

\subsection{Statistical analysis}

The obtained data were subjected to analysis of variance (ANOVA), followed by Duncan's Multiple Range Test for the differences across treatments.

\section{Result and discussion}

\subsection{Raw material composition and kefir characteristics}

The main ingredients of kefir in this study were cow milk and colostrum with particular characteristics. Significant differences were observed in SNF, lactose, protein, and moisture levels (Table 1). Both cow milk and colostrum have passed the Indonesian standard as kefir main ingredients which would affect the chemical quality and generate different characteristics.

The kefir sample was made of $80 \%$ colostrum and $20 \%$ active cow milk as an antioxidant with 318.5 ppm IC50. The score of IC50 isolate was higher than IC50 6.5257 ppm in vitamin C (unpublished data).

Table 2. shows that the titratable acidity (TA) was 1.31 to $1.66 \%$, and the combined treatment with colostrum resulted in a relatively equal TA $(\mathrm{P}>0.05)$. TA score was indicative of increasing as the colostrum percentage was higher; the higher the colostrum, the higher the product TA. This study found that TA was positively 
Table 1. Chemical composition of milk and colostrum as raw materials.

\begin{tabular}{cccc}
\hline Composition & Fresh Milk & Colostrum & $\begin{array}{c}\text { National Standardization Agency of } \\
\text { Indonesia (2011) }\end{array}$ \\
\hline Fat (\%) & 4.87 & 4.82 & min 3.0 \\
Solid Non Fat (\%) & 8.405 & 11.67 & min 7.8 \\
Lactose (\%) & 4.61 & 6.41 & - \\
Protein (\%) & 3.01 & 4.27 & min 2.8 \\
Moisture (\%) & 86.72 & 83.72 & - \\
\hline
\end{tabular}

Table 2. Chemical properties kefir with the addition of colostrum.

\begin{tabular}{|c|c|c|c|c|}
\hline Treatments & $\begin{array}{c}\text { Titratable acidity } \\
(\% \text { lactic acid })\end{array}$ & $\begin{array}{l}\text { Free fatty acids } \\
(\%)\end{array}$ & $\begin{array}{c}\text { Ethanol } \\
(\%)\end{array}$ & $\begin{array}{c}\text { Total solids } \\
(\%)\end{array}$ \\
\hline Milk (100\%) & $1.31 \pm 0.13$ & $4.93 \pm 0.85$ & $0.31 \pm 0.004^{\mathrm{a}}$ & $10.34 \pm 0.93^{\mathrm{a}}$ \\
\hline Milk-colostrum mix (80:20\%) & $1.36 \pm 0.23$ & $4.99 \pm 1.43$ & $0.31 \pm 0.002^{\mathrm{a}}$ & $11.45 \pm 0.29^{\mathrm{ab}}$ \\
\hline Milk-colostrum mix (60:40\%) & $1.49 \pm 0.28$ & $5.37 \pm 0.96$ & $0.35 \pm 0.032^{\mathrm{ab}}$ & $12.56 \pm 1.15^{\mathrm{bc}}$ \\
\hline Milk-colostrum mix (40:60\%) & $1.62 \pm 0.30$ & $5.54 \pm 0.63$ & $0.37 \pm 0.052^{\mathrm{b}}$ & $13.59 \pm 0.89^{c d}$ \\
\hline Milk-colostrum mix (20:80\%) & $1.60 \pm 0.24$ & $5.43 \pm 0.76$ & $0.46 \pm 0.045^{c}$ & $14.10 \pm 0.81^{\mathrm{d}}$ \\
\hline Colostrum (100\%) & $1.66 \pm 0.26$ & $5.36 \pm 0.74$ & $0.50 \pm 0.022^{c}$ & $14.84 \pm 1.32^{\mathrm{d}}$ \\
\hline
\end{tabular}

Different superscripts in the same column show significant differences $(\mathrm{P}<0.05)$. Each treatment was repeated 4 times.

correlated with $\mathrm{pH}$ across treatment, but the highest TA was obtained in kefir made of $100 \%$ colostrum. It was in line with the previous findings (Collar, 1996; Kang et al., 2013) that the decreasing $\mathrm{pH}$ would increase product acidity at the primary storage due to LAB activity that produced metabolic acid. Colostrum contains higher lactose than milk (6.41 vs. $4.61 \%$ ). Lactose is the source of carbohydrate as a substrate for LAB fermentation and converted into lactic acid as the metabolic product. The higher the total lactose would lower $\mathrm{pH}$ and magnify the metabolic. The contributing factors to TA is the type of microbe grown in the media (only LAB or with yeast). $\mathrm{pH}$ value of kefir colostrum is 3.91-3.98 and the TA value in this study was lower than the previous findings, i.e., $2.7 \%$ and $1.3 \%$ on average (Fontán et al., 2006) but higher than 0.7 to $1.4 \%$ (Cetinkaya \& Elal Mus, 2012). According to Özdestan \& Üren (2010) kefir pH was between 4.11 and 4.53, and kefir TA varied from $0.652 \%$ to $1.047 \%$.

Free Fatty Acids (FFA) kefir was between 4.93 and 5.54\%, and the combined treatment using colostrum yielded relatively similar FFA ( $\mathrm{P}>0.05)$. The highest FFA was observed in $40 \%$ cow milk $+60 \%$ colostrum. FFA value indicated lipolysis in fermentation, and the oxidation product was ketone, which contributed to generate aroma (Hassan et al., 2013). Flavor is an essential precursor in volatile compound synthesis (Bassoli et al., 2014; Mikulec et al., 2010). Total FFA increase was parallel to fat and volatile compound (Bao et al., 2016). FFA value in this study was lower than that of the previous study on goat milk, i.e., 5.11 to $8.59 \%$ (Setyawardani et al., 2017).

Ethanol content in kefir was 0.31 to $0.50 \%$, and the combined treatment using colostrum produced different ethanol level $(\mathrm{P}<0.05)$. The higher the colostrum percentage in kefir making, the higher the ethanol. Ethanol is produced from metabolic yeast such as $S$. cerevisiae. Heterofermentative LAB also produces ethanol (Güzel-Seydim et al., 2000; Magalhães et al., 2011; Magalhães et al., 2010). Ethanol is produced by the yeast in kefir grain to inhibit other metabolic activity such as lactic acid/acetic acid produced by other microorganisms in kefir grains (Yoo et al., 2013). Heterofermentative bacteria which produce ethanol in kefir grains include Lactobacillus kefiri and Leuconostoc spp. (Miguel et al., 2011). According to Farnworth (2005) kefir contains low concentrate alcohol produced by yeast in the kefir grain. Genus Acetobacter has a high-concentrate maltic compound in yeast, and $\mathrm{LAB}$ increases aldehyde reduction into alcohol when $\mathrm{LAB}$ harness ethanol for fermentation. LAB for fermentation process may include Lactococcus lactis ssp. lactis, Lactococcus lactis ssp. cremoris, and Leuconostoc; mesenteroides ssp. Cremoris (Cais-Sokolińska et al., 2015).

Kefir total solid was 10.34 to $14.84 \%$, and the combined treatment with colostrum produced different total solid $(\mathrm{P}<0.05)$. A higher percentage of colostrum for kefir would increase total solid. Cow milk has a lower SNF than colostrum (8.405 vs. 11.67\%). Additionally, the total solid of the main ingredients is an essential factor in the quality of the fermentation product. A study on yogurt by Nguyen et al. (2014) stated that total solid is the crucial factor to yogurt quality and other properties such as fat globule, fat surface, lactose concentration, calcium concentration and physical characteristics.

Table 3 shows that kefir made of combined ingredients (cow milk and colostrum) contained 85.15 to $89.33 \%$ moisture. The treatment significantly affected $(\mathrm{P}<0.05)$ kefir moisture, which depleted as the total solid increased, and affected by the increasing percentage of colostrum as the main ingredients. Kefir moisture was lower than the previous finding (Setyawardani \& Sumarmono, 2015) i.e., 87.103 to 89.841 on goat milk kefir stored in a cool or frozen state. The type of raw material affects acidity, dry matter, protein and $\mathrm{CO}_{2}$ kefir, but does not affect microbiological characteristics (Tomar et al., 2019).

Kefir made of combined ingredients (cow milk and colostrum) contained 3.80 to $7.32 \%$ protein. The treatment significantly affected $(\mathrm{P}<0.05)$ protein content in kefir. Different amount of 
protein in a product, including fermentation product, is due to the main ingredients. Cow milk and colostrum have different protein level (3.01 vs. 4.27). The present study showed that the fermentation process could increase the total protein of a product because some LAB in kefir grain produced an enzyme that increased the protein level. Protein in kefir is affected by the type of milk, for example, Saanen goat milk yielded higher kefir protein than that of thick-haired goats. The protein kefir in this study was higher than the previous findings, i.e., $3.37-4.79 \%$ (Satir \& Guzel-Seydim, 2016) and $3.30-4.16 \%$ of goat milk kefir (Setyawardani \& Sumarmono, 2015).

Fat content in kefir made of combined treatments with colostrum addition was relatively similar $(\mathrm{P}>0.05)$ around $1.47-3.06 \%$. Fat content was affected bu the main ingredients; similar fat content in the main ingredients produced relatively similar fat in kefir. Similar fat content in the main ingredients produced relatively similar fat in kefir. It was in line with previous findings by Setyawardani et al. (2017) that goat milk kefir made of different kefir grain percentage would result in similar fat content, i.e., $4.17-5.17 \%$. LAB in kefir grains could produce lipase enzyme that would be released during the fermentation and in the shelf.

Table 3 shows that ash content of kefir ranged from 0.60 to $0.80 \%(\mathrm{P}<0.05)$. Ash is a part of total solid in kefir during the fermentation process which undergoes conversion. The higher the colostrum, the higher the ash content. The lowest ash content was found in kefir made of $20 \%$ colostrum but not significantly different from kefir made of $100 \%$ cow milk. Furthermore, the total solid of the treatment was the least compared to $40 \%$ colostrum. This result was higher than 0.55 to $0.66 \%$ of the previous findings Kök-Taş et al. (2013) but lower than $0.84-0.89 \%$ (Setyawardani et al., 2017).

\subsection{Fatty acids profiles}

Table 4. showed that kefir made of combined ingredients (cow milk and colostrum) had 28 fatty acids. The highest average across treatments includes the palmitic acid (C16:0); oleic acid (C18:1n9c); stearic acid (C18:0) and myristic acid (C14:0), respectively. The result showed that fatty acid in cow milk-kefir colostrum was dominated by saturated fatty acid (60.71\%), and the rest was unsaturated fatty acid (39.29\%). The highest saturated fatty acids (SFA) was palmitic acid (C16:0); $54.54 \%$ poly unsaturated fatty acids (PUFA) and $45.45 \%$ monounsaturated fatty acids (MUFA) of the total USFA. Therefore, the higher the colostrum, the higher the palmitic acid (C16:0) but the lower stearic acid (C18:0) and oleic acid (C18:1n9c). The USFA helps lower the cholesterol and diminish the risk of coronary disease due to the increased high-density lipoprotein (HDL) in the blood (Boycheva et al., 2012).

\subsection{Amino acids}

Table 5. showed that the highest percentage of total amino acid in $100 \%$ colostrum kefir was $7.21 \% \mathrm{w} / \mathrm{w}$. It was similar to kefir made of more colostrum than cow milk. The highest amino acid component was a glutamic amino acid, i.e., 1.90\% w/w. The glutamic amino acid plays an essential role in generating aroma. Also, kefir aroma is affected by acidity level generated by the symbiosis of lactic acid bacteria (LAB) and yeast in kefir grain and influenced by its variety (Leite et al., 2012; Magalhães et al., 2011). The most significant amino acid components in kefir made of cow milk, cow milk - colostrum or $100 \%$ colostrum were glutamic acid, leucine, lysine, and aspartic acid, respectively, while the smallest amino acid was methanoic acid. Kefir grains consist of LAB and yeast in a polysaccharide matrix, and yeast could degrade casein into peptide and amino acid as the precursor aroma of fermentation product (Wong \& Watson, 1995).

\subsection{Microbiological properties}

Table 6. shows that the combined raw materials (cow milk and colostrum) for making kefir does not affect total microbial ( $\mathrm{P}>0.05)$, which averaged 6.37 to $7.51 \mathrm{log} \mathrm{CFU} / \mathrm{ml}$. Microbe consists of bacteria, $\mathrm{LAB}$, mold, and yeast, and the growth is affected by the nutrition content of the raw materials. Lactose is higher in colostrum than in cow milk (6.49 vs. $4.57 \%$ ) (unpublished data). Total bacteria tend to increase when more colostrum is factored in the combined raw materials. The highest total bacteria was found in a combined $20 \%$ cow milk $+80 \%$ colostrum. Total bacteria were linear to $\mathrm{LAB}$ the higher the colostrum, the higher the LAB. Accordingly, combined raw materials for making kefir significantly affects $L A B$ proportion in kefir $(\mathrm{P}<0.05)$.

Total yeast in the present study was 5.54-6.55 $\log \mathrm{CFU} / \mathrm{ml}$ and exhibited a significant effect $(\mathrm{P}<0.05)$. This result is relevant to Setyawardani \& Sumarmono (2015) reporting 6.76 $\pm 0.39 \log$ CFU $/ \mathrm{ml}$ yeast in kefir made of goat milk. Yeast is a dominant microbe in kefir grains. Witthuhn et al. (2005) suggests that LAB and yeast proportion in kefir grains was $6.4 \times 10^{4}$ to $8.5 \times 10^{8}$ and $5 \times 10^{5}$ to $3.7 \times 10^{8} \mathrm{CFU} / \mathrm{ml}$, respectively, while other study suggested that yeast in kefir is about $10^{3} \mathrm{cfu} / \mathrm{ml}$ to $10^{6}$ (Hsieh et al., 2012).

Water activity is a requirement for food products. Low aw value reflects a restrained microbial growth. Table 6 shows that the

Table 3. Proximate composition of kefir with the addition of colostrum.

\begin{tabular}{|c|c|c|c|c|}
\hline Treatments & Moisture (\%) & Protein (\%) & Fat $(\%)$ & Ash (\%) \\
\hline Milk (100\%) & $89.33 \pm 0.43^{\mathrm{d}}$ & $3.80 \pm 0.79^{a}$ & $3.06 \pm 2.47$ & $0.68 \pm 0.04^{\mathrm{ab}}$ \\
\hline Milk-colostrum mix (80:20\%) & $88.48 \pm 0.32^{\mathrm{d}}$ & $3.90 \pm 0.38^{\mathrm{a}}$ & $1.64 \pm 0.41$ & $0.62 \pm 0.16^{\mathrm{a}}$ \\
\hline Milk-colostrum mix (60:40\%) & $87.33 \pm 0.85^{c}$ & $5.20 \pm 1.33^{\mathrm{ab}}$ & $1.47 \pm 1.04$ & $0.80 \pm 0.04^{\mathrm{b}}$ \\
\hline Milk-colostrum mix (40:60\%) & $86.41 \pm 0.88^{b c}$ & $4.59 \pm 0.65^{\mathrm{ab}}$ & $2.78 \pm 2.58$ & $0.77 \pm 0.04^{\mathrm{ab}}$ \\
\hline Milk-colostrum mix (20:80\%) & $85.92 \pm 0.85^{\mathrm{ab}}$ & $5.80 \pm 0.60^{\mathrm{b}}$ & $2.04 \pm 1.58$ & $0.75 \pm 0.16^{\mathrm{ab}}$ \\
\hline Colostrum (100\%) & $85.15 \pm 0.86^{\mathrm{a}}$ & $7.32 \pm 1.44^{c}$ & $2.09 \pm 1.12$ & $0.79 \pm 0.03^{b}$ \\
\hline
\end{tabular}

Different superscripts in the same column show significant differences $(\mathrm{P}<0.05)$. Each treatment was repeated 4 times. 
Table 4. Fatty acid profiles of kefir produced from milk, colostrum and milk-colostrum mixes.

\begin{tabular}{|c|c|c|c|c|c|c|}
\hline \multirow{2}{*}{ Components } & \multicolumn{6}{|c|}{ Proportion of colostrum in the mixes (\%) } \\
\hline & 0 & 20 & 40 & 60 & 80 & 100 \\
\hline Butiric acid, C4:0 & 0.59 & 0.54 & 0.72 & 0.66 & 0.66 & 0.50 \\
\hline Caproic acid, C6:0 & 0.61 & 0.44 & 0.67 & 0.61 & 0.62 & 0.51 \\
\hline Caprilic acid, C8:0 & 0.45 & 0.36 & 0.51 & 0.48 & 0.47 & 0.41 \\
\hline Capric acid, C10:0 & 1.20 & 0.96 & 1.30 & 1.26 & 1.23 & 1.15 \\
\hline Undeconoic acid,C11:0 & 0.07 & 0.08 & 0.11 & 0.08 & 0.08 & 0.04 \\
\hline Myristic acid, C14:0 & 8.75 & 8.59 & 10.19 & 9.24 & 9.50 & 9.95 \\
\hline Myristoleic acid, C14:1 & 0.36 & 0.61 & 0.63 & 0.47 & 0.44 & 0.32 \\
\hline Pentadecanoic acid, C15:0 & 0.47 & 0.54 & 0.54 & 0.49 & 0.49 & 0.51 \\
\hline Palmitic acid, C16:0 & 28.47 & 23.78 & 28.72 & 28.55 & 29.09 & 31.76 \\
\hline Palmitoleic acid, C16:1 & 1.30 & 1.54 & 1.43 & 1.31 & 1.22 & 1.07 \\
\hline Oleic acid C18, $\ln 9 \mathrm{c}$ & 22.02 & 21.47 & 19.80 & 20.68 & 19.45 & 18.30 \\
\hline Linoleic acid, C18:2n6c & 1.86 & 1.17 & 1.43 & 1.68 & 1.75 & 2.03 \\
\hline Arachidic acid, C20:0 & 0.10 & 0.10 & 0.09 & 0.09 & 0.10 & 0.11 \\
\hline$\Gamma$-Linolenic acid,C18:3n6 & - & - & - & 0.02 & 0.02 & 0.02 \\
\hline Cis-11Eicosenoic acid,C20:1 & 0.04 & 0.06 & 0.06 & 0.04 & 0.04 & 0.04 \\
\hline Linolenic acid,C18:3n3 & 0.20 & 0.12 & 0.20 & 0.21 & 0.22 & 0.23 \\
\hline Heneicosanoic acid, C21:0 & - & 0.02 & 0.03 & 0.03 & 0.03 & 0.03 \\
\hline Cis-11,14-Eicosedienoic acid,C20:2 & 0.04 & - & 0.02 & - & - & 0.03 \\
\hline Behenic acid,C22:0 & 0.04 & 0.05 & 0.03 & 0.02 & 0.03 & 0.04 \\
\hline Cis-8,11,14-Eicosentrienoic acid, C20:3n6 & 0.07 & 0.05 & 0.05 & 0.06 & 0.10 & 0.13 \\
\hline Arachidonic acid,C20:4n6 & 0.15 & 0.08 & 0.10 & 0.13 & 0.16 & 0.20 \\
\hline
\end{tabular}

Table 5. Amino acids profiles of kefir produced from milk, colostrum and milk-colostrum mixes.

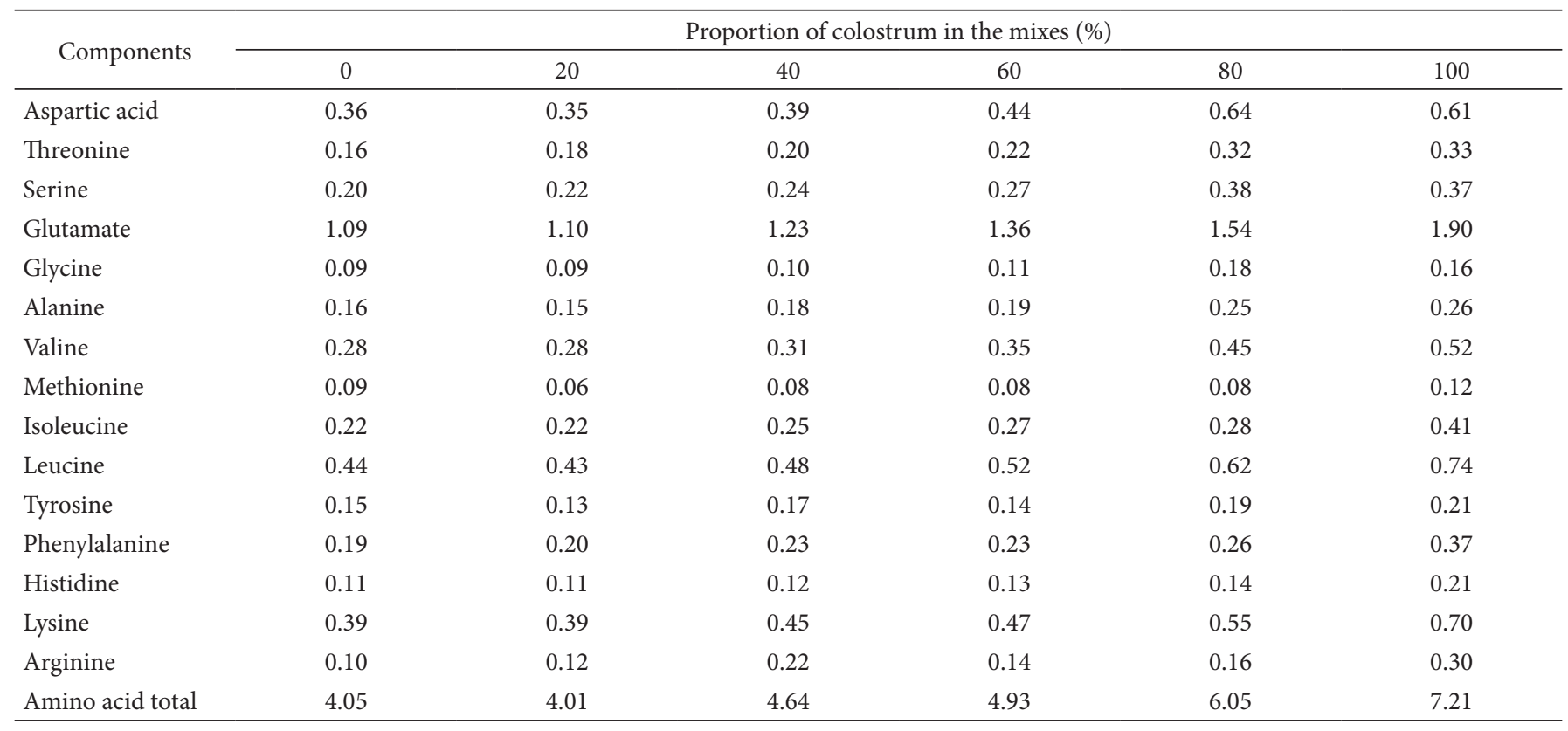


Table 6. Microbiological characteristics and water activity of kefir produced from milk, colostrum, and milk-colostrum mixes.

\begin{tabular}{lccccc}
\hline \multicolumn{1}{c}{ Treatments } & $\begin{array}{c}\text { Total microbes } \\
(\log \text { CFU/mL) }\end{array}$ & $\begin{array}{c}\text { Total bacteria } \\
(\log \text { CFU/mL) }\end{array}$ & $\begin{array}{c}\text { Total lactic acid } \\
\text { bacteria } \\
(\log \text { CFU/mL) }\end{array}$ & $\begin{array}{c}\text { Total yeast } \\
(\log \text { CFU/mL) }\end{array}$ & Water activity \\
\hline Milk (100\%) & $7.51 \pm 0.84$ & $7.49 \pm 0.19^{\mathrm{ab}}$ & $7.20 \pm 0.30^{\mathrm{ab}}$ & $6.15 \pm 0.61^{\mathrm{ab}}$ & $0.89 \pm 0.02^{\mathrm{b}}$ \\
Milk-colostrum mix (80:20\%) & $7.10 \pm 0.59$ & $7.64 \pm 0.71^{\mathrm{ab}}$ & $6.92 \pm 0.35^{\mathrm{a}}$ & $5.74 \pm 0.31^{\mathrm{a}}$ & $0.89 \pm 0.02^{\mathrm{b}}$ \\
Milk-colostrum mix (60:40\%) & $7.26 \pm 0.80$ & $7.04 \pm 0.16^{\mathrm{a}}$ & $7.08 \pm 0.02^{\mathrm{ab}}$ & $5.59 \pm 0.17^{\mathrm{a}}$ & $0.88 \pm 0.02^{\mathrm{ab}}$ \\
Milk-colostrum mix (40:60\%) & $6.78 \pm 0.65$ & $7.97 \pm 0.55^{\mathrm{b}}$ & $7.42 \pm 0.23^{\mathrm{b}}$ & $5.54 \pm 0.62^{\mathrm{a}}$ & $0.86 \pm 0.01^{\mathrm{ab}}$ \\
Milk-colostrum mix (20:80\%) & $7.09 \pm 0.71$ & $8.23 \pm 0.70^{\mathrm{b}}$ & $7.48 \pm 0.29^{\mathrm{b}}$ & $6.55 \pm 0.11^{\mathrm{b}}$ & $0.85 \pm 0.01^{\mathrm{a}}$ \\
Colostrum (100\%) & $6.37 \pm 0.33$ & $7.89 \pm 0.73^{\mathrm{ab}}$ & $7.15 \pm 0.25^{\mathrm{ab}}$ & $5.98 \pm 0.59^{\mathrm{a}}$ & $0.85 \pm 0.02^{\mathrm{ab}}$ \\
\hline
\end{tabular}

Different superscripts in the same column show significant differences $(\mathrm{P}<0.05)$. Each treatment was repeated 4 times.

combined cow milk and colostrum for making kefir generated an average 0.85-0.89 aw, but the highest aw was found in kefir made of $100 \%$ cow milk. Different aw value in fermentation showed a modification in intracellular accumulation and extracellular excretion from the product (Gervais \& Molin, 2003).

Lactose, as the source of carbohydrate, cannot optimize the growth of microbe. Therefore, increasing colostrum (20-100\%) would reduce the total microbes in kefir because antimicrobial properties generated by colostrum decrease the microbe. Colostrum exhibits a high antimicrobial ability in inhibiting E.coli, E.aerogenes, K.pneumonieae, B.subtilis, and S.aureus (Viswanathan et al., 2015). Lactobacilli (65-80\%) dominates microbial population in kefir grain (Wouters et al., 2002) and it is the biggest bacteria in kefir. Furthermore, yeast and acetate acid bacteria contribute to kefir flavor. Microbe composition in kefir depends on kefir source, substrate, culture, and method of culture preservation (Gao et al., 2012).

Total bacteria in kefir is dominated by lactic acid bacteria, including homofermentative and heterofermentative bacteria (Cheirsilp \& Radchabut, 2011). Bacteria formed a symbiosis with yeast in kefir grain and produced bio-product as the source of growth for the microbe. Yeast and kefir grain play a role in generating lactic acid and ethanol (Hamet et al., 2013).

Kefir grain is dominated by lactic acid bacteria, i.e., Lactobacillus paracasei ssp. paracasei, Lactobacillus acidophilus, Lactobacillus delbrueckii ssp. bulgaricus, Lactobacillus plantarum, and L. kefiranofaciens, but only $20 \%$ of kefir contained Lactobacillus, and the rest is Lactobacillus kefir (80\%) (Zanirati et al., 2015). Kefir made of combined cow milk and colostrum generated $6.92-7.48 \log$ CFU/ml LAB. Similarly, kefir made of goat milk and different kefir grains generated $7.17 \pm 0.92 \log \mathrm{CFU} / \mathrm{ml}$ total LAB (Setyawardani \& Sumarmono, 2015). By increasing the use of colostrum, the growth of LAB in kefir is improved because $\mathrm{LAB}$ maximizes substrate lactose function in fermentation and producing lactic acid.

Yeast plays an important role in fermentation by producing important nutrition such as amino acid and vitamin, modifying $\mathrm{pH}$, and producing ethanol and CO2. Yeast in kefir is synergic for kefir growth that produces metabolite which contributes to kefir flavor and aroma (Farnworth, 2005). Yeast grows in an acidic condition as a metabolite produced by LAB that would generate metabolite products ethanol and CO2. Lactic acid bacteria and yeast produce various homeostatic essential vitamin, mineral, and amino acid. Shewanella, Acinetobacter, Pelomonas, Dysgonomonas, and Weissella are microorganism in kefir (Arslan, 2015). The role of yeast in lactic acid synthesis depends on its ability in using protein, fat, lactose, and citrate. Several studies (Álvarez-Martín et al., 2008) reported the correlation between yeast growth and milk product in metabolizing lactic acid (Cais-Sokolińska et al., 2015). In general, yeast is an acidophilic organism that grows very well in an acidic condition with optimal pH 4 to 6 (Anton et al., 2016).

The water activity (aw) value for bacteria and yeast is different; the higher the colostrum percentage lower the aw value. The average aw in this research is relevant to the previous research at 0.88 on goat milk kefir incubated for 30 days (source?). The water food system significantly contributed to the appearance, texture, and flavor, and serves as a solvent in the metabolism process (Setyawardani \& Sumarmono, 2015).

\subsection{Antimicrobial properties of kefir}

Figure 1. shows that combined raw material for making kefir inhibited several pathogenic bacteria, i.e., S.aureus $(6 \mathrm{~mm}$, the smallest), E.coli (8.08-10.21mm), S. typhimurium (6-11.62mm), and P.aeruginosa. (8.43-11.42mm). In general, the biggest inhibition among all pathogenic bacteria was on kefir with a combined $80 \%$ cow milk and $20 \%$ colostrum. Antimicrobial properties of kefir are generated from metabolite during the fermentation process which produces lactic acid, antibiotic, and bactericide that inhibit bacterial growth and pathogenic microbe (Liu et al., 2002). The previous study suggests that kefir metabolite could inhibit pathogenic bacteria such as Salmonella, Helicobacter, Shigella, Staphylococcus, Escherichia coli, Enterobacter aerogenes, Proteus vulgaris, Bacillus subtilis, Micrococcus luteus, Listeria monocytogenes, Streptococcus pyrogenes (Prado et al., 2015).

One of the inhibitory mechanisms was by lowering $\mathrm{pH}$ by LAB metabolites, i.e., lactic acid and acetic acid (Tejero-Sariñena et al., 2012). Antimicrobial activity is derived from lactic acid and other organic acids (Teneva et al., 2017). The main role of antimicrobial components in food preservation is by inhibiting or deactivating pathogenic or food-decaying bacteria (Davidson \& Zivanovic, 2003). Antimicrobial was important for food safety and to reduce damage due to decomposer microbes. Kefir contains several metabolite and inhibitors such as organic acid, peroxide hydrogen, ethyl alcohol, diacetyl, peptide, and bacteriocins. The metabolites are interacting to improve antimicrobial 


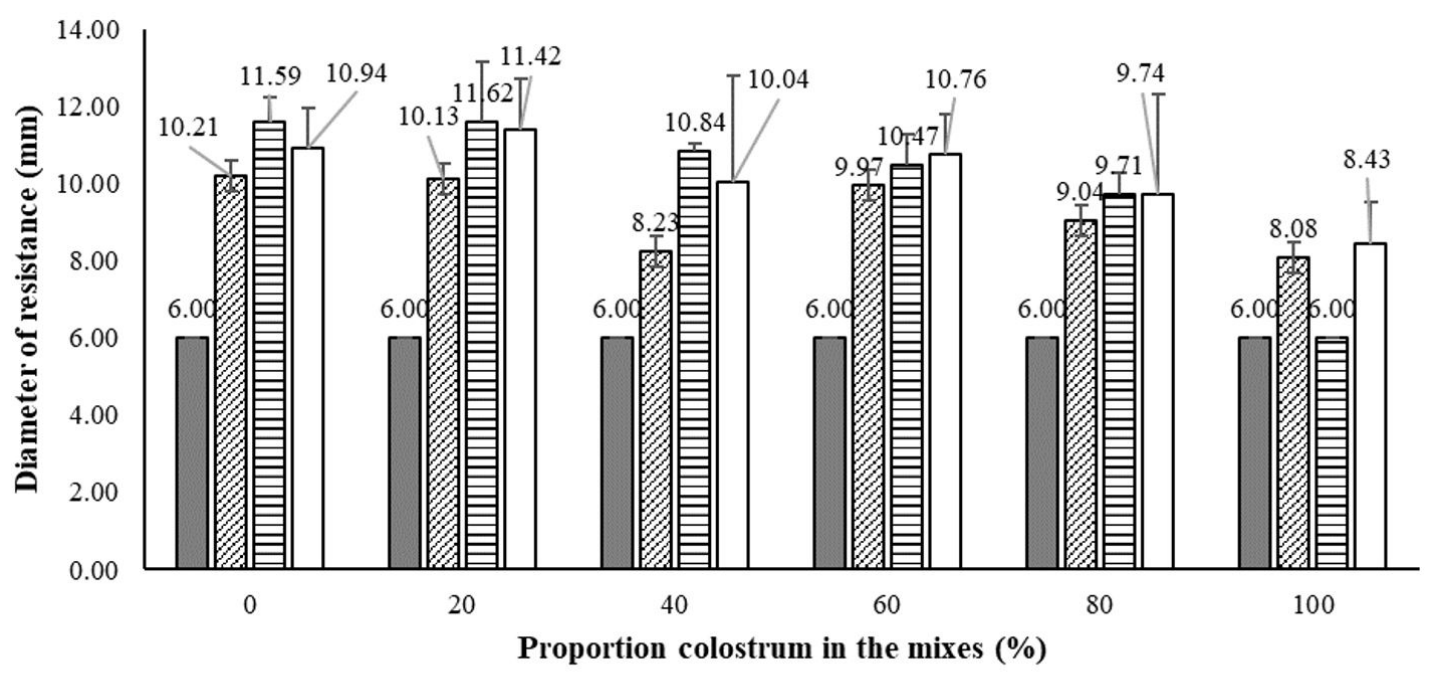

$\square$ S.aureus $\square$ E.coli $\square$ S.thyphimurium $\square$ P. aeruginosa

Figure 1. Inhibition of kefir on pathogenic bacteria.

activity (Kim et al., 2015). Antimicrobial activity is affected by low $\mathrm{pH}$, and antimicrobial generated during kefir fermentation (Kim et al., 2016).

For future studies, it will be interesting to comprehend the perception of consumers on kefir produced from colostrum or milk-colostrum mixes. Kefir is one of fermented milk products with low lactose content, acidic taste and slightly effervescent, which may influence consumer's acceptance. Nevertheless, in general, consumers perceived fermented milk as healthy food products with striking sensory characteristics (Pinto et al., 2018). The perception of consumers on kefir can be assessed by the use of projective techniques, which are word association and Haire' shopping list (Pinto et al., 2018) or free word association method (Judacewski et al., 2019).

\section{Conclusion}

Our investigation showed that higher percentage of colostrum produced kefir with higher ethanol, total solid, protein, and total amino acid contents. Addition of colostrum to the milk improved palmitic acid content of the kefir, however, stearic and oleic acids contents tended to reduce. Highest total microbes, bacteria, lactic acid bacteria and yeast was observed in kefir produce from milk-colostrum mix (20:80\%). In addition, kefir produced from milk, colostrum and milk-colostrum mixes exhibit antimicrobial properties against S. aureus, S. typhimurium, E. coli, and P. aeruginosa bacteria. These characteristics are imperative for the practical application of kefir produced from milk-colostrum mixes. The use of milk-colostrum mixes for manufacturing kefir is a novelty, and it produces kefir with particular composition and functional characteristics.

\section{Acknowledgements}

The study received financial support from the Ministry of Research, Technology and Higher Education of Indonesia through the Fundamental Research Grant No. 111/UN/23.14/ PN.01.00/2019).

\section{References}

Álvarez-Martín, P., Flórez, A. B., Hernández-Barranco, A., \& Mayo, B. (2008). Interaction between dairy yeasts and lactic acid bacteria strains during milk fermentation. Food Control, 19(1), 62-70. http:// dx.doi.org/10.1016/j.foodcont.2007.02.003.

Anton, D., Raudsepp, P., Roasto, M., Meremäe, K., Kuusik, S., Toomik, P., Elias, P., Laikoja, K., Kaart, T., \& Lepiku, M. (2016). Comparative study of microbiological, chemical and sensory properties of kefirs produced in Estonia, Latvia and Lithuania. Journal of Dairy Research, 83(1), 89-95. http://dx.doi.org/10.1017/S0022029915000710.

Arslan, S. (2015). A review: chemical, microbiological and nutritional characteristics of kefir. CYTA: Journal of Food, 13(3), 340-345. http:// dx.doi.org/10.1080/19476337.2014.981588.

Association of Official Analytical Chemists - AOAC. (2006). Official methods of analysis of the Association of Official Analytical Chemists $\left(15^{\text {th }}\right.$ ed.). Virginia: AOAC.

Bao, Z., Xiong, J., Lin, W., \& Ye, J. (2016). Profiles of free fatty acids, free amino acids, and volatile compounds of milk bases fermented by Lactobacillus casei GBHM-21 with different fat levels. CYTA: Journal of Food, 14(1), 10-17. http://dx.doi.org/10.1080/1947633 7.2015.1035673.

Bassoli, A., Borgonovo, G., Caremoli, F., \& Mancuso, G. (2014). The taste of D-and L-amino acids: In vitro binding assays with cloned human bitter (TAS2Rs) and sweet (TAS1R2/TAS1R3) receptors. Food Chemistry, 150, 27-33. http://dx.doi.org/10.1016/j. foodchem.2013.10.106. PMid:24360415.

Boycheva, S., Mihaylova, G., Naydenova, N., \& Dimitrov, T. (2012). Amino acid and fatty acid content of yogurt supplemented with walnut and hazelnut pieces. Trakia Journal of Sciences, 10(2), 17-25.

Cais-Sokolińska, D., Wójtowski, J., Pikul, J., Danków, R., Majcher, M., Teichert, J., \& Bagnicka, E. (2015). Formation of volatile compounds in kefir made of goat and sheep milk with high polyunsaturated fatty acid content. Journal of Dairy Science, 98(10), 6692-6705. http:// dx.doi.org/10.3168/jds.2015-9441. PMid:26277315.

Ceniti, C., Froiio, F., Britti, D., Paolino, D., \& Costanzo, N. (2019). Rheological characteristics of bovine colostrum and their correlation with immunoglobulin G. International Journal of Dairy Technology, 72(3), 345-349. http://dx.doi.org/10.1111/1471-0307.12593. 
Cetinkaya, F., \& Elal Mus, T. (2012). Determination of microbiological and chemical characteristics of kefir consumed in Bursa. Ankara Üniversitesi Veteriner Fakültesi Dergisi, 59, 217-221. http://dx.doi. org/10.1501/Vetfak_0000002528.

Cheirsilp, B., \& Radchabut, S. (2011). Use of whey lactose from dairy industry for economical kefiran production by Lactobacillus kefiranofaciens in mixed cultures with yeasts. New Biotechnology, 28(6), 574-580. http://dx.doi.org/10.1016/j.nbt.2011.01.009. PMid:21315193.

Collar, C. (1996). Biochemical and technological assessment of the metabolism of pure and mixed cultures of yeast and lactic acid bacteria in breadmaking applications/revisión: aspectos bioquímicos y tecnológicos del metabolismo de cultivos puros y mixtos de levaduras y bacterias ácido lácticas en panificación. Food Science and Technology International, 2(6), 349-367. http://dx.doi.org/https:// doi.org/10.1177\%2F108201329600200601.

Davidson, P. M., \& Zivanovic, S. (2003). The use of natural antimicrobials. In P. Zeuthen \& L. Bogh-Sorenson (Eds.), Food preservation techniques (pp. 5-30). Cambridge, United Kingdom: Woodhead Publishing. http://dx.doi.org/10.1533/9781855737143.1.5.

Demirci, A. S., Palabiyik, I., Ozalp, S., \& Tirpanci Sivri, G. (2019). Effect of using kefir in the formulation of traditional Tarhana. Food Science and Technology (Campinas), 39(2), 358-364. http://dx.doi. org/10.1590/fst.29817.

Farnworth, E. R. (2005). Kefir-a complex probiotic. Food Science and Technology Bulletin: Functional Foods, 2(1), 1-17. http://dx.doi. org/10.1616/1476-2137.13938.

Fontán, M. C. G., Martínez, S., Franco, I., \& Carballo, J. (2006). Microbiological and chemical changes during the manufacture of Kefir made from cows' milk, using a commercial starter culture. International Dairy Journal, 16(7), 762-767. http://dx.doi.org/10.1016/j. idairyj.2005.07.004.

Gao, J., Gu, F., Abdella, N. H., Ruan, H., \& He, G. (2012). Investigation on culturable microflora in Tibetan kefir grains from different areas of China. Journal of Food Science, 77(8), M425-M433. http://dx.doi. org/10.1111/j.1750-3841.2012.02805.x. PMid:22860591.

Gervais, P., \& Molin, P. (2003). The role of water in solid-state fermentation. Biochemical Engineering Journal, 13(2-3), 85-101. http://dx.doi.org/10.1016/S1369-703X(02)00122-5.

Gul, O., Atalar, I., Mortas, M., \& Dervisoglu, M. (2018). Rheological, textural, colour and sensorial properties of kefir produced with buffalo milk using kefir grains and starter culture: A comparison with cows' milk kefir. International Journal of Dairy Technology, 71, 73-80. http://dx.doi.org/10.1111/1471-0307.12503.

Güzel-Seydim, Z. B., Seydim, A. C., Greene, A. K., \& Bodine, A. B. (2000). Determination of Organic Acids and Volatile Flavor Substances in Kefir during Fermentation. Journal of Food Composition and Analysis, 13(1), 35-43. http://dx.doi.org/10.1006/jfca.1999.0842.

Hamet, M. F., Londero, A., Medrano, M., Vercammen, E., Van Hoorde, K., Garrote, G. L., Huys, G., Vandamme, P., \& Abraham, A. G. (2013). Application of culture-dependent and culture-independent methods for the identification of Lactobacillus kefiranofaciens in microbial consortia present in kefir grains. Food Microbiology, 36(2), 327334. http://dx.doi.org/10.1016/j.fm.2013.06.022. PMid:24010614.

Hassan, F. A., El-Gawad, M. A. M. A., \& Enab, A. (2013). Flavour compounds in cheese [review]. Research on Precision Instrument and Machinery, 2(2), 15-29. http://dx.doi.org/10.7813/20754124.2012/4-5/A.20.

Hsieh, H.-H., Wang, S.-Y., Chen, T.-L., Huang, Y.-L., \& Chen, M.-J. (2012). Effects of cow's and goat's milk as fermentation media on the microbial ecology of sugary kefir grains. International Journal of Food Microbiology, 157(1), 73-81. http://dx.doi.org/10.1016/j. ijfoodmicro.2012.04.014. PMid:22578996.

Hyrslova, I., Krausova, G., Bartova, J., Kolesar, L., \& Curda, L. (2016). Goat and bovine colostrum as a basis for new probiotic functional foods and dietary supplements. Journal Microbial \& Biochemical Technology, 8, 56-59. http://dx.doi.org/10.4172/1948-5948.1000262.

Judacewski, P., Los, P. R., Lima, L. S., Alberti, A., Zielinski, A. A. F., \& Nogueira, A. (2019). Perceptions of Brazilian consumers regarding white mould surface-ripened cheese using free word association. International Journal of Dairy Technology, 72(4), 585-590. http:// dx.doi.org/10.1111/1471-0307.12649.

Kang, K.-M., Park, C.-S., \& Lee, S.-H. (2013). Effects of D-tagatose on the growth of intestinal microflora and the fermentation of yogurt. Journal of the Korean Society of Food Science and Nutrition, 42(3), 348-354. http://dx.doi.org/10.3746/jkfn.2013.42.3.348.

Karaçalı, R., Özdemİr, N. İ., \& Çon, A. H. (2018). Aromatic and functional aspects of kefir produced using soya milk and Bifidobacterium species. International Journal of Dairy Technology, 71(4), 921-933. http://dx.doi.org/10.1111/1471-0307.12537.

Kim, D.-H., Chon, J.-W., Kang, I.-B., Kim, H., Kim, H.-S., Song, K.-Y., \& Seo, K.-H. (2015). Growth inhibition of Cronobacter sakazakii in experimentally contaminated powdered infant formula by kefir supernatant. Journal of Food Protection, 78(9), 1651-1655. http:// dx.doi.org/10.4315/0362-028X.JFP-15-119. PMid:26319718.

Kim, D.-H., Jeong, D., Kim, H., Kang, I.-B., Chon, J.-W., Song, K.-Y., \& Seo, K.-H. (2016). Antimicrobial activity of kefir against various food pathogens and spoilage bacteria. Korean Journal for Food Science of Animal Resources, 36(6), 787-790. https://dx.doi.org/10. 5851\%2Fkosfa.2016.36.6.787.

Kivanc, M., \& Yapici, E. (2018). Survival of Escherichia coli O157: H7 and Staphylococcus aureus during the fermentation and storage of kefir. Food Science and Technology (Campinas), 39(Suppl. 1), 225230. http://dx.doi.org/10.1590/fst.39517.

Kök-Taş, T., Seydim, A. C., Özer, B., \& Guzel-Seydim, Z. B. (2013). Effects of different fermentation parameters on quality characteristics of kefir. Journal of Dairy Science, 96(2), 780-789. http://dx.doi. org/10.3168/jds.2012-5753. PMid:23245957.

Leite, A. M., Mayo, B., Rachid, C. T., Peixoto, R., Silva, J., Paschoalin, V., \& Delgado, S. (2012). Assessment of the microbial diversity of Brazilian kefir grains by PCR-DGGE and pyrosequencing analysis. Food Microbiology, 31(2), 215-221. http://dx.doi.org/10.1016/j. fm.2012.03.011. PMid:22608226.

Liu, J.-R., Wang, S.-Y., Lin, Y.-Y., \& Lin, C.-W. (2002). Antitumor activity of milk kefir and soy milk kefir in tumor-bearing mice. Nutrition and Cancer, 44(2), 183-187. http://dx.doi.org/10.1207/ S15327914NC4402_10. PMid:12734066.

Magalhães, K. T., de Melo Pereira, G. V., Campos, C. R., Dragone, G., \& Schwan, R. F. (2011). Brazilian kefir: structure, microbial communities and chemical composition. Brazilian Journal of Microbiology, 42(2), 693-702. http://dx.doi.org/10.1590/S1517-83822011000200034. PMid:24031681.

Magalhães, K. T., Pereira, M. A., Nicolau, A., Dragone, G., Domingues, L., Teixeira, J. A., de Almeida Silva, J. B., \& Schwan, R. F. (2010). Production of fermented cheese whey-based beverage using kefir grains as starter culture: Evaluation of morphological and microbial variations. Bioresource Technology, 101(22), 8843-8850. http://dx.doi. org/10.1016/j.biortech.2010.06.083. PMid:20619643.

Miguel, M. G., Cardoso, P. G., Magalhães, K. T., \& Schwan, R. F. (2011). Profile of microbial communities present in tibico (sugary kefir) grains from different Brazilian States. World Journal of Microbiology 
\& Biotechnology, 27(8), 1875-1884. http://dx.doi.org/10.1007/ s11274-010-0646-6.

Mikulec, N., Habuš, I., Antunac, N., Vitale, L., \& Havranek, J. (2010). Influence of peptide and amino acids on the formation of cheese flavour. Mljekarstvo: časopis za unaprjeđenje proizvodnje i prerade mlijeka, 60(4), 219-227.

National Standardization Agency of Indonesia - BSN (2011). Indonesian standard reference for fresh milk part 1: cow's milk (SNI 3141.1: 2011). Jakarta: Badan Standardisasi Nasional Indonesia.

Nguyen, H. T. H., Ong, L., Lefèvre, C., Kentish, S. E., \& Gras, S. L. (2014). The microstructure and physicochemical properties of probiotic buffalo yoghurt during fermentation and storage: a comparison with bovine yoghurt. Food and Bioprocess Technology, 7(4), 937-953. http://dx.doi.org/10.1007/s11947-013-1082-z.

Özdestan, Ö., \& Üren, A. (2010). Biogenic amine content of kefir: a fermented dairy product. European Food Research and Technology, 231(1), 101-107. http://dx.doi.org/10.1007/s00217-010-1258-y.

Pinto, L. P. F., Silva, H. L. A., Kuriya, S. P., Maçaira, P. M., Cyrino Oliveira, F. L., Cruz, A. G., Esmerino, E. A., \& Freitas, M. Q. (2018). Understanding perceptions and beliefs about different types of fermented milks through the application of projective techniques: A case study using Haire's shopping list and free word association. Journal of Sensory Studies, 33(3), e12326. http://dx.doi.org/10.1111/ joss. 12326.

Prado, M. R., Blandón, L. M., Vandenberghe, L. P., Rodrigues, C., Castro, G. R., Thomaz-Soccol, V., \& Soccol, C. R. (2015). Milk kefir: composition, microbial cultures, biological activities, and related products. Frontiers in Microbiology, 6, 1177. http://dx.doi. org/10.3389/fmicb.2015.01177. PMid:26579086.

Satir, G., \& Guzel-Seydim, Z. B. (2016). How kefir fermentation can affect product composition? Small Ruminant Research, 134, 1-7. http://dx.doi.org/10.1016/j.smallrumres.2015.10.022.

Setyawardani, T., \& Sumarmono, J. (2015). Chemical and microbiological characteristics of goat milk kefir during storage under different temperatures. Journal of The Indonesian Tropical Animal Agriculture, 40(3), 183-187. http://dx.doi.org/10.14710/jitaa.40.3.183-188.

Setyawardani, T., Sumarmono, J., Rahardjo, A. H. D., Sulistyowati, M., \& Widayaka, K. (2017). Chemical, physical and sensory quality of goat milk kefir during storage under different temperatures. Bulletin of Animal Science, 41(3), 298-306. http://dx.doi.org/10.21059/ buletinpeternak.v41i3.18266.

Silva, E. G. D. S. O., Santos, F. L., Santana, L. R. R. D., Silva, M. V. L., \& Conceicao, T. D. A. (2018). Development and characterization of a soymilk Kefir-based functional beverage. Food Science and Technology (Campinas), 38(3), 543-550. http://dx.doi.org/10.1590/1678-457x.10617.
Silva, E. G. S. O., Rangel, A. H. N., Mürmam, L., Bezerra, M. F., \& Oliveira, J. P. F. (2019). Bovine colostrum: benefits of its use in human food. Food Science and Technology (Campinas), 39(Suppl 2), 355-362. http://dx.doi.org/10.1590/fst.14619.

Tejero-Sariñena, S., Barlow, J., Costabile, A., Gibson, G. R., \& Rowland, I. (2012). In vitro evaluation of the antimicrobial activity of a range of probiotics against pathogens: Evidence for the effects of organic acids. Anaerobe, 18(5), 530-538. http://dx.doi.org/10.1016/j. anaerobe.2012.08.004. PMid:22959627.

Teneva, D., Denkova, R., Goranov, B., Denkova, Z., \& Kostov, G. (2017). Antimicrobial activity of Lactobacillus plantarum strains against Salmonella pathogens. Ukrainian Food Journal, 6(1), 125-133. http:// dx.doi.org/10.24263/2304-974X-2017-6-1-14.

Tomar, O., Akarca, G., Çaglar, A., Beykaya, M., \& Gok, V. (2019). The effects of kefir grain and starter culture on kefir produced from cow and buffalo milk during storage periods. Food Science and Technology (Campinas), 40(1), 238-244. http://dx.doi.org/10.1590/fst.39418.

Viswanathan, S., Preethi, G., Veilumuthu, P., Rajesh, M. A. R., \& Suba, P. (2015). Probiotic studies in colostrum of buffalo. Global Veterinaria, 14(2), 199-204. http://dx.doi.org/10.5829/idosi.gv.2015.14.02.92179.

Witthuhn, R., Schoeman, T., \& Britz, T. (2005). Characterisation of the microbial population at different stages of Kefir production and Kefir grain mass cultivation. International Dairy Journal, 15(4), 383-389. http://dx.doi.org/10.1016/j.idairyj.2004.07.016.

Wong, C. W., \& Watson, D. L. (1995). Immunomodulatory effects of dietary whey proteins in mice. The Journal of Dairy Research, 62(2), 359-368. http://dx.doi.org/10.1017/S0022029900031058. PMid:7601980.

Wouters, J. T. M., Ayad, E. H. E., Hugenholtz, J., \& Smit, G. (2002). Microbes from raw milk for fermented dairy products. International Dairy Journal, 12(2-3), 91-109. http://dx.doi.org/10.1016/S09586946(01)00151-0.

Yoo, S. H., Seong, K. S., \& Yoon, S. S. (2013). Physicochemical properties of kefir manufactured by a two-step fermentation. Food Science of Animal Resources, 33(6), 744-751. http://dx.doi.org/10.5851/ kosfa.2013.33.6.744.

Zanirati, D. F., Abatemarco, M., Jr., Sandes, S. H. C., Nicoli, J. R., Nunes, Á. C., \& Neumann, E. (2015). Selection of lactic acid bacteria from Brazilian kefir grains for potential use as starter or probiotic cultures. Anaerobe, 32, 70-76. http://dx.doi.org/10.1016/j.anaerobe.2014.12.007. PMid:25542841.

Zeynep, N., Tontul, I., Aşçi Arslan, A., Sahin Nadeem, H., \& Kucukcetin, A. (2018). Microbial viability, physicochemical and sensory properties of kefir microcapsules prepared using maltodextrin/Arabic gum mixes. International Journal of Dairy Technology, 71, 61-72. http:// dx.doi.org/10.1111/1471-0307.12402. 